\title{
Simülasyon Öğretim Yönteminin Ortaokul Öğrencilerinin Afetlere Karşı Hazırlık Durumlarına Etkisi**
}

\author{
Can ŞAHAN ${ }^{1 *}$, Ayten DiNÇ ${ }^{2}$
}

\section{Öz}

$\mathrm{Bu}$ araştırma, simülasyon öğretim yöntemi kullanılarak verilen afet ve deprem eğitimlerinin ortaokul öğrencilerinin afetlere karşı hazırlık durumlarına etkisinin incelenmesi amacıyla yapılmış deneysel bir çalışmadır. Araştırmanın evrenini Fevzi Çakmak Ortaokulunda okuyan tüm öğrenciler oluştururken örneklemini ise Fevzi Çakmak Ortaokulu 7. sınıfta öğrenim gören öğrenciler oluşturmaktadır. Çalışmanın deney $(\mathrm{N}=48)$ ve kontrol $(\mathrm{N}=48)$ grupları seçkisiz atama yöntemi ile oluşturulmuştur. Araştırma sürecinde deney grubu öğrencilerine Afet Eğitim Merkezi'nde (BAEM) bulunan simülasyonlar aracılığıyla, kontrol grubuna ise okulda geleneksel yöntemle (düz anlatım, gösterip yaptırma) afetler ve depremden korunma yolları eğitimi verilmiştir. Her iki gruba da eğitim öncesi ön test ve eğitimden 2 ay sonra son test uygulanmıştır. Verilerin analizi için SPSS-22 (Statistical Package for the Social Sciences) paket programı kullanılmıştır. Hazırlık düzeyleri karşılaştırıııken bağımlı değişkenler için McNemar testi, bağımsız değişkenler için ise Ki-Kare testi yapılmıştır. Araştırma bulgularına göre, deney grubu öğrencilerin eğitim sonrasında afet planı hazırlama, afet ve acil durum çantası hazırlama ve buluşma noktası belirleme konularında daha hazırlıklı oldukları ancak kontrol grubunun hazırlık düzeylerinde bu bakımdan herhangi bir değişiklik olmadığı saptanmıştır. Sonuç olarak simülasyon öğretim yönteminin afet eğitimlerinde oldukça etkin olduğu saptanmıştır. Afetlere karşı dirençli bir toplum oluşturmak için bu tür eğitimler okullarda daha fazla verilmeli ve afet eğitim merkezleri daha etkin kullanılmalıdır.

Anahtar Kelimeler: Afet, Afet Eğitimi, Dirençlilik, Afet Bilinci.

\section{The Effect of Simulation Teaching Method on Middle School Students' Preparedness for Disasters}

\begin{abstract}
This research is an experimental study conducted in order to examine the effect of disaster and earthquake trainings given by using simulation teaching method on disaster preparedness of middle school students in Bursa Disaster Education Center. The population of the study consists of all students studying at Fevzi Çakmak Secondary School and the sample consists of 7th grade students at Fevzi Çakmak Secondary School. Experimental (N $=48)$ and control $(\mathrm{N}=48)$ groups of the study were selected by simple random sampling method. During the research process, experimental group students were trained through simulations in the Disaster Training Center, and the control group was trained in the traditional method (direct instruction, demonstration and making) of disasters and ways of protection from earthquakes. Pre-test before the training and post-test 2 months after the training was applied to both groups. SPSS-22 (Statistical Package for the Social Sciences)

\footnotetext{
${ }^{1}$ Amasya Üniversitesi Suluova Meslek Yüksekokulu, Mülkiyet Koruma ve Güvenlik Bölümü, Amasya

2 Çanakkale Onsekiz Mart Üniversitesi, Sağlık Bilimleri Fakültesi Ebelik Bölümü ,Çanakkale.

*ilgili yazar / Corresponding author: can.sahan@amasya.edu.tr

*Bu çalışma 03.01.2019 tarihinde başarıyla savunulan yüksek lisans tezinden oluş̧urulmuştur ve 13-15 Ocak 2020 tarihleri arasında gerçekleştirlen 2.Uluslararası Afet Direnclilik Kongresinde özet bildiri olarak sunulmustur.

Gönderim Tarihi / Received Date: 07.10.2020

Kabul Tarihi / Accepted Date: 09.01.2021
} 
package program was used for data analysis. McNemar test for dependent variables and chisquare analysis for independent variables were used to compare the preparedness levels. According to the findings of the research, it was determined that the experimental group students were better prepared for disaster planning, disaster and emergency bag preparation and meeting point determination after the training, but there was no change in the control group in this regard. As a result, it has been determined that the simulation teaching method is very effective in disaster preparedness training. In order to be a disaster-resistant society, it can be suggested that such trainings should be given more place in schools and more effective use of disaster education centers.

Keywords: Disaster, Disaster Education, Resilience, Disaster Awareness.

\section{Giriş}

Afetler insanoğlunun varoluşundan bu yana birçok zarar ve kayıplara neden olmaktadır. Dünya ve ülkemiz zaman zaman çeşitli afetlerin etkisi altına girmiştir ve hala girmektedir. Dünyada her yıl 150 milyon insan afete maruz kalmaktadır. Ülkemizde ise 1995'ten günümüze kadar meydana gelmiş afetlerde 22.000 'den fazla insan yaşamını yitirmiştir (Kaya ve Özcebe 2012). Ülkemiz tektonik oluşumu, jeolojik ve meteorolojik yapısı nedeni ile deprem, sel, heyelan, çı̆̆, kaya düşmesi, kuraklık gibi birçok doğal afet riskine açık bir bölgededir (Ergünay, 2007). Öte yandan ülkemizde göçler, terör olayları, kazalar gibi insan ve teknoloji kaynaklı olaylarda gitgide artmaktadır.

Günümüzde geleneksel afet yönetimi yerine modern afet yönetimine geçiş söz konusudur. Geçmiş yıllarda meydana gelen afetlerde geleneksel afet yönetiminin etkisiz ve yetersiz olduğu anlaşıımıştır. Bundan dolayı modern afet yönetimi kapsamında olan afet risk yönetimi odaklı anlayışa geçiş hızlanmıştır (Özmen ve Özden, 2013). Geleneksel afet yönetiminde, tehlikelerin kendisine önem verilmiş, tehlikenin oluşmasına neden olacak asıl sebeplere ve krizi meydana getiren altta yatan nedenlere yani risk yönetimine önem verilmemiştir. Risk yönetimi denilince zarara ve hasara neden olacak olumsuzlukları belirlemek, kontrol altına almak, sakınmak, zarar azaltma veya yönetmek için yapılan çalışmalar akla gelmektedir (Cardona, 2003).

Risk yönetimi odaklı afet yönetimi anlayışı ile afet güvenliği sağlanmış olacaktır (Arıkan, 2019). Afet güvenliği ile afetlere karşı dirençlilik kavramları arasında sıkı bir ilişki bulunmaktadır. UNISDR 2009, yaptığı tanımlamaya göre; afetlerde dirençlilik; bir tehlikeye maruz kalmış bir sistemin ya da toplumun, temel yapılarının korunması ve yenilenmesi de dahil olmak üzere, tehlikenin meydana getirdiği olumsuz etkilerini hızlı ve etkili bir şekilde sönümleme, afet öncesi hayata dönüş ve iyileşme yeteneğidir. Afet güvenliği ise afetler sonrasında meydana gelebilecek zarar ve kayıpları azaltmak veya yok etmek için alınan önlemleri ve hazırlıkların tümünü kapsamaktadır (Arıkan, 2019).

Afetlere karşı dirençli bir toplum oluşturmanın yolu afet güvenliğinden geçmektedir. Afetlere karşı dirençli bir toplum oluşturmakla aslında bireylerin ve toplumun kendisini güvende hissedebileceği bir ortam oluşturulmuş olacaktır. Dirençli bir toplum ile ifade edilmek istenen risk azaltma bilincine ve afetlerle baş etme kapasitesine sahip bir toplumdur. Dirençli bir toplum oluşturmada eğitimlerin rolünün çok büyük olduğu söylenebilir (Varol ve Kırıkkaya, 2017).

Ülkemizde toplumun afetlere karşı farkındalığını arttırmak için büyük çaba gösterilmektedir Afet ve acil durumlarda risklerinin önlenmesi veya vereceği zararın minimize edilmesi ancak dirençli bir toplum oluşturmakla mümkündür. Dirençli bir toplum oluşturmanın temel şartları ise düzenlenecek farkındalık eğitimleri ve kapasite geliştirme programlarıdır (UNISDR, 2005). 
Topluma dirençlilik kazandırmada eğitim önemli bir unsur olarak görülmektedir. Ülkemizdeki her bireye temel afet bilinci kültürünü kazandırmak çok zordur. Tabi ki bu bilinçlendirme eğitimleri farklı kurumlar tarafından küçümsenmeyecek ölçüde düzenlenmektedir. Ancak yeterli insan gücünün olmaması ve maliyet gibi nedenlerle sürdürülebilir olmamasından dolayı bu eğitimler yeterli olmamaktadır (Varol ve Kırıkkaya, 2017).

On Birinci Kalkınma Planında Afet Yönetimi başlığı altında farkındalık eğitimleri ile ilgili maddeler bulunaktadır. Bu maddeler "Afet ve acil durumlara karşı toplumsal farkındalık artırılacak ve yerel düzeyde afet yönetiminden sorumlu birimlerin kapasiteleri güçlendirilecektir." ve "Afet ve acil durumlara karşı ülke genelinde bilinçlendirme çalışmaları yapılacak, eğitim ve farkındalık merkezleri aracılığı ile toplumsal farkındalığın artırılması sağlanacaktır." şeklindedir (Kalkınma Bakanlığı, 2019) Kalkınma planına bakıldığında hedefleri arasında afet eğitimlerinin yer aldığı görülmektedir. Sonuç olarak afet zararlarının azaltılması ve toplumun afetlere karşı direnç kazandırılmasında etkin rol oynayan unsurun eğitim olduğu ortaya çıkmaktadır. Eğitimler afetlerin etkin bir şekilde yönetilmesini sağlayan unsurlardan bir tanesidir. Eğitimler sayesinde afetlerin neden olacağı can ve mal kayıpları önlenebilir veya azaltılabilir (Varol ve Kırıkkaya, 2017).

Eğitim programlarının düzenlenmesi bakımından 1999 depremleri milat olarak kabul edilebilir. Bu depremler sonrasında Milli Eğitim Bakanlığı, Boğaziçi Üniversitesi, Kandilli Rasathanesi ve Deprem Araştırma Enstitüsü, Türk Kızılayı, üniversiteler ve belediyeler gibi birçok kurum ve kuruluş tarafından afetlerin etkilerini azaltmak ve afet bilinci kültürünü oluşturmak amacıyla eğitim programları düzenlenmiştir (Sanduvac \& Petal, 2010). Ancak bu eğitim programlarının süreklilik arz etmemesi ve eğitim ve öğretim sistemi içerisine entegre edilememesi önemli bir sorun teşkil etmektedir. Karancı ve diğerleri (2005) tarafından yapılan çalışmada bu tür eğitim programlarının katılımcıları motive ettiğini ancak kalıcı olarak davranış değişikliğine yol açmadığını tespit edilmiştir. Bunun yanında aynı çalışmada bu eğitimlerin bireylerin gelecekte meydana gelebilecek afetlerle ilgili kaygı düzeylerini düşürdüğünü ve eğitim seviyesi yükseldikçe endişe seviyelerinin ise azaldığını belirtmişlerdir.

AFAD, 2013 yılında, başlayarak felaketler konusunda bilinçlendirmek ve Türk toplumunda "felaketlere duyarlı bir yaşam kültürü" yaratmak için "Afete Hazırlanan Türkiye" kampanyasını başlatmıştır. Afete Hazırlanan Türkiye temalı bu eğitim kampanyası kapsamında, "Afete Hazırlanan Aileler", "Afete Hazırlanan Okullar", "Afete Hazır İşyeri" ve "Afete Hazır Gönüllü Gençler" kampanyaları yürütülmüştür. "Afete Hazırlanan Okul" kampanyasını etkili bir şekilde yürütmek için Milli Eğitim Bakanlığı (MEB) ile bir protokol imzalanmıştır. Tüm okullarda afet ve acil durum planlamaları yapılmış ve eğitim sonrasında simülasyon çalışmaları İstanbul'da gerçekleştirilmiştir (URL-1).

Bu konuda başka bir çalışma ise "Okul Tabanlı Afet Eğitim Projesi" dir. Proje, JICA ve MEB tarafından 18 Ekim 2010 yılında imzalanan anlaşma ile okullarda idari görevlilerin, öğretmenlerin, öğrencilerin ve velilerin afet bilincinin arttırılması ve afet zararlarının minimize edilmesi amacıyla oluşturulmuştur. 2011 yılında başlatılan projenin süresi 3 yıl olarak belirlenmiştir. Ancak 6 ay daha uzatılarak 2014 haziran ayında sonlandırımıştır. Proje kapsamında, 10 pilot ilden seçilen 80 ilköğretim okulunda, 7.000 öğretmene eğitimler verilmiştir (Özmen ve İnce, 2017).

Yapılan en yeni çalışma ise, Türk İşbirliği ve Koordinasyon Ajansı Başkanlığı (TíKA), Japonya Uluslararası İşbirliği Ajansı (JICA) ve Orta Doğu Teknik Üniversitesinin (ODTÜ), işbirliğinde "Afet Risklerinin Yönetimi ve Afete Karşı Dirençli Toplumların Oluşturulması" konulu eğitim programı hazırlanmıştır. Bu kapsamda TIKKA, JICA ve ODTÜ tarafından, sürdürülebilir kalkınma hedefleri açısından da büyük önem taşıyan Afet Risk Yönetimi ve 
Afete Karşı Dirençli Toplumlar yetiştirilmesi alanında her yıl iki haftalık olmak üzere üç yıl süreli eğitim programı düzenleme kararı alınmıştır (URL-2).

İnsanoğlu teknolojinin gelişmesine rağmen afetler karşısında yapabilecekleri sınırıdır. Aynı zamanda günümüz bilimi hala afetlerin oluşmasını engelleyemediği gibi, afetlerin nerede ve ne zaman meydana geleceği ve şiddetinin ne olacağı konusunda net bilgiler verememektedir. Bu durumda insanoğlunun afetlere karşı çeşitli önlemleri alması ve hazırlıklı olması gerekmektedir (Bilik, 2017)

Risk yönetim odaklı afet yönetiminin önem kazandığı günümüzde topluma da çok büyük sorumluluklar düşmektedir. Çünkü toplumun paydaş olarak dahil edilmediği afet yönetimi yaklaşımıyla başarılı olmak çok mümkün değildir. Bireyler kendi yaşamlarında önlem almadıkları, riskleri azaltmak için gerekli çalışmaları ve afetlere karşı hiçbir hazırlık yapmadıkları sürece afet yönetiminin başarılı olması söz konusu değildir. Bundan dolayı hazırlıklı olma kapsamında bireyler tarafından aile afet planının ve afet ve acil durum çantasının hazırlanması ve aile afet ve acil durum buluşma noktasının belirlenmesi büyük önem arz etmektedir. Aynı zamanda afet öncesi, sırası ve sonrasındaki doğru hareket davranışlarının neler olduğu bireyler tarafından bilinmesi etkin bir afet yönetiminin şartlarından biridir (Akgüngör, 2013).

Bir afet meydana geldiğinde resmi yardım ekipleri olay yerine tam anlamıyla 12-24 saat aralığında ulaşmaktadır (Karaesmen, 2002). Operasyon ekiplerinin olay yerine ilk dakikalarda ulaşması mümkün değildir. Yardım ekiplerinin olay yerine tam anlamıyla ulaşması 72 saati bulmaktadır. Bundan dolayı afet sonrası ilk 72 saat kritik saatler olarak değerlendirilmektedir. Bu süre içerisinde kazazedeler dışarıdan izoledirler ve kurtarılanların çoğu yakınları veya hayatta kalmış afetzedeler tarafından kurtarılmaktadır. Bu süreçte kişilerin hayatta kalabilmeleri ve hayatlarını idame ettirebilmeleri, öncesinde yapmış oldukları hazırlıklarla doğru orantılıdır. Halkın afetlere karşı hazırlıklı olması afet eğitimlerinden geçmektedir (URL-3).

Günümüzde temel afet bilinci ve korunma eğitimleri başta okullar ve AFAD olmak üzere birçok kurum ve kuruluş tarafından verilmektedir. Afet eğitimi İlkokulda Hayat Bilgisi ve Sosyal Bilgiler dersleri bünyesinde, ortaokulda ise Fen Bilimleri dersi bünyesinde bazı üniteler kapsamında verilmektedir (URL-4; URL-5 ve URL-6). Ancak bu eğitimlerin etkililiği ve yeterliliği tartışılabilir. Ayrıca yapılan çalışmalarda sınıf öğretmeni, sosyal bilgiler öğretmeni ve fen bilimleri öğretmeni adaylarının afet eğitimi konusunda bilgilerinin sınırlı olduğu belirtilmiş ve aynı zamanda öğretmen adaylarının afetlerle ilgili yanlış inanışlara sahip olduğu saptanmıştır (Öcal ve diğerleri, 2016; Cin, 2010; Dikmenli ve Yakar, 2019). Başka bir çalışmada öğretmen adaylarının doğal kaynaklı afet okuryazarlık düzeylerinin orta düzeyin çok az üzerinde çıktığı görülmüştür. Ancak yine de yeterli olduğu düşünülmemektedir. Öte yandan öğretmen adaylarının duyarlıık düzeyi yüksek çıkmasına rağmen bireysel ve toplumsal hazırlık düzeylerinin orta düzeyin alt bandında kaldığı görülmüştür. Davranış boyutuna bakıldığında ise öğretmen adaylarının davranış düzeyleri orta düzeyde çıktığı gözlemlenmiştir.

Davranış boyutu kavramı eğitim de öğrenilen bilgilerin özümsenerek içselleştirilmesi ve davranışa dönüştürülmesidir (Sözcü ve Aydınözü, 2019). Afet eğitimlerinde sadece bilgi sahibi olmak değil aynı zamanda bu bilgiyi davranışa dökebilmek önemlidir. Özellikle öğretmenler bu konuda öğrencilerine örnek olmalıdır. Çünkü anlatıların etkili olması veya davranışa dönüştürülmesinin sağlanabilmesi için öğretmenlerin anlattıkları ile davranışlarının tutarlı olması gerekmektedir. Öğretmenlerin öncelikle afetlerle ilgili her türlü bilgiye sahip olmaları ve afete karşı hazırıklı olmaları gerekmektedir. Yapılan çalışmalarda söz konusu 
öğretmen adayları, lisans eğitimi sürecinde üniversiteden üniversiteye farklılı göstermekle birlikte afetle ilgili ders almadıklarını belirtmişlerdir. Öğretmenlerin afetlerle ilgili yeterli bilgi birikimine sahip olmamaları ve yanlış inanışlara sahip olmaları demek öğrencilerin de afetlerle ilgili yetersiz bilgiye ve mitolojik inanışlara sahip olmaları demektir. Bu konuyu destekleyecek olan çalışmalara bakıldığında ilkokul veya ortaokul seviyesindeki öğrencilerin afetlerle ilgili yetersiz bilgi düzeyine ve yanlış inanışlara sahip oldukları görülmektedir (Karakuş ve Önger, 2017: Turan ve Kartal, 2012; Şimşek, 2007; Oğuz, 2005) Bu durum öğretmenden, öğretim yönteminden veya kişisel nedenlerden kaynaklı olabilmektedir.

Okullar haricinde AFAD tarafından da farklı öğretim yöntemleri kullanılarak afet eğitimleri verilmektedir. Kırıkkaya ve diğerlerinin (2011) "fen ve teknoloji öğretmenlerinin ilköğretim fen ve teknoloji programında yer alan afet eğitimi konularına ilişkin öğretmen görüşleri" adlı çalışmasında fen ve teknoloji öğretmenlerinin \%50'si afet eğitimlerinin Afet Eğitim Merkezi, Kızılay vb. kurum ve kuruluşlarda yapılması gerektiğini belirtmiştir. Ülkemizde AFAD bünyesinde Ankara, İzmir, Bursa vb illerde bu merkezler bulunmaktadır. Buralarda simülasyon öğretim yöntemi başta olmak üzere öğrencilerin ilgisini çekebileceği farklı öğretim yöntemlerinden yararlanılmaktadır. Afetlerle ilgili konuların hem soyut hem de ezbere dayalı olması sebebiyle bu eğitimler öğrencilerin hem anlama düzeylerini zorlamakta hem de eğitimler sırasında öğrenciler sıkılmaktadırlar. Bu konuda Sharp, Mackintosh ve Seedhouse (1995)'un İngiltere' de yaptıkları çalışmada pek çok ilkokul öğrencisinin (5-11 yaş) depremin nedenlerini çok az bir kısmını anladıklarını ortaya koymuşlardır. Bu nedenle afetlerle ilgili eğitimlerin sadece bilgi düzeylerini arttırma amaçlı değil bu bilgileri somutlaştırarak öğretmeye ve öğrendikleri bilgileri uygulatmaya yönelik olması gerekmektedir. Bu açıdan Afet Eğitim Merkezinde verilen afet eğitimleri sırasında kullanılan simülasyonlar sayesinde soyut bilgiler somutlaştırılarak öğrencilerin konuyu daha kolay kavramalarını, eğlenirken öğrenmelerini sağlamakta ve aynı zamanda sıkılmalarını da engellemektedir.

Literatüre bakıldığında afet eğitimlerinin farklı öğretim yöntemleri kullanılarak verilmesinin öğrencileri afet bilgi düzeylerine etkisi incelenmiş deneysel çalışmalar bulunmaktadır (Doğan ve Koç, 2017; Karataş, 2011, Özgüven, 2016, Erdoğ, 2010). Ancak öğrencilerin öğrendikleri bilgileri davranışa dönüştürüp dönüştürmediğini deneysel yöntem kullanılarak yapılmış, simülasyon öğretim yönteminin etkisi inceleyen bir çalışma bulunmamaktadır. Bilgi düzeyleri önemli olduğu kadar öğrendikleri bilgileri davranışa dönüştürüp dönüştürmedikleri de bir o kadar önemlidir. Özgüven 2016 "ilköğretim öğrencilerine verilen temel afet bilinci eğitiminin bilgi düzeyine etkisi" adlı deneysel araştırma türlerinden tek grup ön test-son test desenle yapmış olduğu araştırmasında aile afet planı hazırlık durularına etkisini, öğretim yöntemi olarak düz anlatımı, soru cevabı, demonstrasyonu ve gösterip yaptırmayı kullanarak ortaya koymaya çalışmıştır. Ancak bu tür modelde kontrol grubu olmadığı için meydana gelecek farkın her zaman kullanılan öğretim yönteminden kaynaklandığını söylemek mümkün değildir.

Bu çalışmada Bursa Afet Eğitim Merkezi'nde (BAEM) videolarla ve görsellerle desteklenmiş simülasyon yöntemi kullanılarak verilen afet ve deprem eğitimlerinin ortaokul öğrencilerinin afetlere hazırlık düzeylerine etkisi incelenmiştir. BAEM'de simülatörler kullanılarak verilen afetler ve depremden korunma eğitimlerinin öğrencilerin aile afet ve acil durum planı hazırlama, afet ve acil durum çantası hazırlama ve afet ve acil durum buluşma noktası belirleme durumlarına etkisi ortaya konulmaya çalışıımıştır.

Bu amaç doğrultusunda araştırma "Temel afet bilinci ve depremden korunma yolları konuları işlenirken kullanılan simülasyon öğretim yönteminin öğrencilerin afet ve acil durumlara karşı hazırlık durumlarına etkisi nedir? problem cümlesi üzerinde temellendirilmiştir. Problem cümlesinin alt problemleri ise şu şekildedir; 
- Aile afet planı hazırlık durumları açısından deney ve kontrol grubu öğrencileri arasında anlamlı bir fark var mıdır?

- Afet ve acil durum çantası hazırlık durumları açısından deney ve kontrol grubu öğrencileri arasında anlamlı bir fark var mıdır?

- Aile afet ve acil durum buluşma noktası belirleme açısından deney ve kontrol grubu öğrencileri arasında anlamlı bir fark var mıdır?

\section{Yöntem}

\subsection{Araştırmanın modeli}

Bu araştırma, ortaokul 7. sınıf öğrencilerine temel afet bilinci ve depremden korunma yolları konularını simülasyon öğretim yöntemi kullanılarak verilmesinin öğrencilerin afet ve acil durumlara hazırlık durumlarının üzerindeki etkisinin incelendiği, deneysel modelde yapılmış bir çalışmadır.

Deneme modeli bilimsel araştırma yöntemleri arasında araştırmacı tarafından işlemlerin karşılaştırılabilir tarzda yapılması ve devamında etkilerinin incelenmesi, en kesin sonuçları veren bir model olmasını sağlamaktadır. Sonuç olarak bu model bağımsı değişkenlerin bağımlı değişkenler üzerinde etkisinin olup olmadığının araştırıması işlemidir (Büyüköztürk ve diğ, 2015).

Bu çalışmada afetten ve depremden korunma eğitimlerinin simülatörler aracıllığıyla verildiği BAEM'in öğrencilerin afet ve acil durumlara karşı hazırlık durumlarına etkisini ortaya koymak amacıyla deney ve kontrol grupları oluşturularak "statik grup öntest-sontest denkleştirilmemiş yarı deneysel desen" ile araştırma yapılmıştır. Deney grubu; afetten ve depremden korunma konularını simülasyon öğretim yöntemi ile işlendiği grup, kontrol grubu ise aynı konuların geleneksel (düz anlatım, gösterip yaptırma) yöntemle işlendiği gruptur. Eğitim öncesinde her iki gruba ön test ve eğitimden iki ay sonra olmak üzere son test uygulanmıştır.

\subsection{Araştırmanın evreni ve örneklem}

Araştırmanın evrenini Bursa ilinin merkezinde bulunan Fevzi Çakmak Ortaokulunda okuyan öğrenciler oluşturmaktadır. Maliyet ve zaman gibi sorunların oluşmaması adına bu okul seçilmiştir. Bu okulun tercih edilmesinin nedeni okulun BAEM'e yürüme mesafesinde olmasıdır. Çalışmanın hem uygulanabilir olması ve hem de kolay ulaşılabilir olması açısından uygun örnekleme yöntemi kullanılarak örneklem olarak Fevzi Çakmak Ortaokulu 7. sınıfta öğrenim gören öğrenciler seçilmiştir. Bu yaş seviyesindeki çocukların araştırma için uygun olacağı düşünülmektedir. Çünkü 12 yaşından itibaren çocuklar soyut kavramları anlayarak etkili çözüm yolları aramaya başlarlar (Gündüz, 2009). Bundan dolayı 7. sınıf öğrencileri yaş ve zihinsel gelişim düzeyleri gibi özellikler nedeniyle bu çalışmaya dahil edilmişlerdir

Çalışma grubu seçkisiz atama ile 7 sınıfta öğrenim gören 100 öğrenciden oluşmaktadır. Toplamda öğrencilerin \%96'sı çalışmada yer almıştır. Deney ve kontrol grubu 48'er öğrenciden oluşmaktadır. Araştırmanın yapıldığı dönemde okulda 7. sınıfta öğrenim gören 6 adet şube vardır. Bu şubelerden dört tanesi ile deney ve kontrol grubu oluşturulmuştur. Okulda ikili öğrenim olmasından dolayı diğer 2 şubeye ulaşılamamıştır.

\subsection{Araştırmanın etik yönü}

Çalışma için önce Bursa İl Milli Eğitim Müdürlüğü ve Bursa AFAD'dan resmi izinler alınmıştır. Aynı zamanda çalışmanın uygulanabilmesi için Çanakkale Onsekiz Mart Üniversitesi Sosyal Bilimler Enstitüsü etik kurulundan da yazılı izin alınmıştır (Karar No: 2017/23). 


\subsection{Veri toplama araçları ve veri toplama yöntemi}

Araştırmanın verilerini toplamak amacıyla literatür doğrultusunda araştırmacı tarafından hazırlanan anket formu kullanılmıştır. Anket formu 11 adet sorudan oluşan tanımlayıcı bilgiler kısmı ile 24 adet çoktan seçmeli sorudan oluşan başarı testi kısmından oluşmaktadır. Anket oluşturma esnasında uzmanların görüşlerine başvurulmuştur. Bu çalışmada sadece tanımlayıcı bilgiler kısmındaki veriler değerlendirilmiştir. Tanımlayıcı bilgiler kısmında sosyodemografik bilgilerle ilgili sorular haricinde "Evet" ve "Hayır" seçeneklerinden oluşan örneklemin afetlere karşı hazırlık durumlarını tespit etmek amacıyla kullanılan sorular bulunmaktadır. Bu sorular BAEM'de eğitim alma durumu, temel afet bilinci eğitimi alma durumu, aile afet planı, afet ve acil durum çantası ve aile afet buluşma noktası hazırlık durumları ile ilgilidir (Özgüven, 2006; Karataş, 2011).

Araştırma 29.11.2017 ile 31.01.2018 tarihleri arasında uygulanmıştır. Çalışmaya başlamadan önce örneklem olarak seçilen gruplara çalışmanın neden yapıldığı ile ilgili bilgi verildikten sonra veli onamı alınarak çalışmaya başlanılmıştır. Deney grubuna afetler ve depremden korunma yolları eğitimi, BAEM'de bulunan simülatörler aracılığıyla verilmiştir. Eğitimden önce ön test (aile afet planı, afet ve acil durum çantası ve aile afet buluşma noktası hazırlık durumları sorgulanmıştır) uygulaması yapılmıştır. Daha sonra deney grubuna simülasyon yöntemiyle afet eğitimi verilmiştir. Deney grubundaki öğrenciler Bilgilendirme odası, Deprem Sarsma Simülasyonu, Deprem Enkaz Sokağı, 5D Deprem Simülasyon Odası, Deprem Sergi Odası, Acil Durum Telefon İhbar Simülasyonuna alınarak önce teorik bilgi verilmiş sonra uygulama yaptırımıştır. Verilen eğitimin hazırlık düzeyine etkisini belirlemek üzere 2 ay sonra son test (kontrol anketi) uygulaması yapılmıştır.

Kontrol grubuna ise afetler ve depremden korunma yolları eğitimi Fevzi Çakmak Ortaokulu Konferans Salonu'nda geleneksel (düz anlatım, gösterip yaptırma, soru-cevap) öğretim yöntemi kullanılarak verilmiştir. Eğitim öncesinde öğrencilere ön test uygulaması yapılmıştır. Eğitimden 2 ay sonra ise yine son test uygulaması yapılmıştır. Eğitimler her iki gruba anket uygulaması da dahil olmak üzere dörder saat verilmiştir.

\subsection{Verilerin analizi ve değerlendirilmesi}

Verilerin değerlendirilmesinde, SPSS 22.0 (Statistical Package for The Social Science) programı kullanılmıştır. Deney ve kontrol grubunun demografik özelliklerini belirlemek için frekans dağılımları incelenmiştir. Aynı zamanda grupların afet ve depremlere karşı hazırlık düzeylerinde eğitim öncesi ve eğitimden 2 ay sonraki anket uygulamasında anlamlı bir fark olup olmadığını belirlemek için bağımlı değişkenler için "Mc Nemar Testi" ve bağımsız değişkenler için ise "Ki-Kare Testi" uygulanmıştır.

\section{Bulgular}

\subsection{Deney ve kontrol grubu öğrencilerini tanıtıcı bulgular}

Tablo 1'de görüldüğü gibi çalışmaya katılan öğrencilerin $\% 61,5$ 'i erkek, $\% 38,5$ 'i ise kızdır. Her iki grup cinsiyet dağılımları bakımından birbirine benzerdir $(P=0,834)$. Araştırmaya katılan öğrenciler 12 ile 14 yaş aralığındadır $(P=0,262)$. Deney ve kontrol grubunun baba eğitim durumları açısından $(P=0,230)$ ve anne eğitim durumları açısından $(P=0,385)$ istatistiksel olarak aralarında anlamlı bir fark yoktur. Bu bakımdan gruplar birbirine benzerdir.

"Afet Eğitim Merkezi'nde daha önceden eğitim aldınız mı?" sorusuna deney grubu öğrencilerinin \%27,1'i evet, \%72,9'u ise hayır olarak; kontrol grubu öğrencilerinin ise \%18,8'i evet, 81,3 'ü ise hayır olarak cevaplamışlardır. Araştırmaya katılan toplam öğrencilerin \%22,9'unu Afet Eğitim Merkezi'nde eğitime katıldıklarını, \%77,1'inin ise katılmadıklarını belirtmişlerdir. Grupların Afet Eğitim Merkezi'nde eğitim alma durumlarına bakıldığında istatistiksel olarak aralarında anlamlı bir fark yoktur $(P=0,331)$. 
"Daha önce temel afet bilinci eğitimi aldınız mı?" sorusuna deney grubu öğrencilerinin $\% 43,8$ 'i evet, \%56,3'ü ise hayır; kontrol grubu öğrencilerinin ise \%35,4'ü evet, \%64,6'sı ise hayır cevabını vermiştir. Çalışmaya katılan öğrencilerin bu soruya toplamda \%39,6'sı evet $\% 60,4$ ise hayır cevabını vermiştir. Grupların eğitim öncesinde afet ve depremden korunma yollarına iliş̧kin eğitim alma durumlarına bakıldığında istatistiksel olarak aralarında anlamlı bir farklılık söz konusu değildir $(P=0,404)$. Gruplar uygulama öncesinde temel afet bilinci eğitimi alma durumları bakımından birbirine benzerdir.

Temel afet bilinci eğitimini alan deney grubu öğrencilerin \%18,8'i okuldan, \%22,9'u AFAD'dan, \%2,1'i diğer kurum ve kuruluşlardan aldığını belirtmiştir. Kontrol grubu öğrencileri ise \%20,8'i okuldan, \%12,5 AFAD'dan, \%2,1'i de diğer kurum ve kuruluşlardan aldığını belirtmiştir. Gruplar eğitim alma yeri bakımından birbirlerine benzerdir $(P=0,573)$.

Deney ve kontrol grupları uygulama öncesinde hazırbulunuşluk ve çeşitli özellikler bakımından birbirine benzerdir. Bu durum bağımlı değişkenler (afet ve acil durumlara hazırlık düzeyleri) üzerinde diğer dışsal değişkenlerin etkisinin olmadığını, sadece öğretim yöntemlerinin etkisinin olduğunu ortaya koyma açısından istenen bir durumdur.

\begin{tabular}{|c|c|c|c|c|c|c|c|}
\hline & \multicolumn{2}{|c|}{ Deney Grubu } & \multicolumn{2}{|c|}{ Kontrol Grubu } & \multirow{2}{*}{$\frac{\text { Toplam }}{\mathrm{n}}$} & \multirow[b]{2}{*}{$\%$} & \multirow[t]{2}{*}{$\mathrm{P}$} \\
\hline & $\mathbf{n}$ & $\%$ & $\mathbf{n}$ & $\%$ & & & \\
\hline \multicolumn{8}{|l|}{ Cinsiyet } \\
\hline Erkek & 29 & 60,4 & 30 & 62,5 & 59 & 61,5 & $x^{2}=0,044$ \\
\hline $\mathrm{K} \mathrm{Iz}$ & 19 & 39,6 & 18 & 37,5 & 37 & 38,5 & $\mathrm{Sd}=1$ \\
\hline Toplam & 48 & 100 & 48 & 100 & 96 & 100 & $p=0,834$ \\
\hline \multicolumn{8}{|l|}{ Yaş } \\
\hline Minimum & 12 & & 12 & & 48 & & $x^{2}=2,680$ \\
\hline Maksimum & 14 & & 14 & & 48 & & $S d=2$ \\
\hline Toplam & & & & & 96 & & $p=0,262$ \\
\hline \multicolumn{8}{|c|}{ Baba Eğitim Durumu } \\
\hline İlkokul & 24 & 50 & 24 & 50 & 48 & 50 & \\
\hline Lise & 22 & 45,8 & 17 & 35,4 & 39 & 40,6 & $x^{2}=4,308$ \\
\hline Önlisans & 2 & 4,2 & 4 & 8,3 & 6 & 6,3 & $\mathrm{Sd}=3$ \\
\hline Lisans & 0 & 0 & 3 & 6,3 & 3 & 3,1 & $p=0,230$ \\
\hline Toplam & 48 & 100 & 48 & 100 & 96 & 100 & \\
\hline \multicolumn{8}{|c|}{ Anne Eğitim Durumu } \\
\hline İlkokul & 34 & 70,8 & 34 & 70,8 & 68 & 70,8 & $x^{2}=3,040$ \\
\hline Lise & 13 & 27,1 & 12 & 25 & 25 & 26 & $\mathrm{Sd}=3$ \\
\hline Önlisans & 0 & 0 & 2 & 4,2 & 2 & 2,1 & $p=0,385$ \\
\hline Lisans & 1 & 2,1 & 0 & 0 & 1 & 1 & \\
\hline Toplam & 48 & 100 & 48 & 100 & 96 & 100 & \\
\hline \multicolumn{8}{|c|}{$\begin{array}{l}\text { Afet Eğitim Merkezi'nde } \\
\text { Eğitim Alma Durumu }\end{array}$} \\
\hline Evet & 13 & 27,1 & 9 & 18,8 & 22 & 22,9 & $x 2=0,943$ \\
\hline Hayır & 35 & 72,9 & 39 & 81,3 & 74 & 77,1 & $\mathrm{Sd}=1$ \\
\hline Toplam & 48 & 100 & 48 & 100 & 96 & 100 & $p=0,331$ \\
\hline \multicolumn{8}{|c|}{$\begin{array}{l}\text { Temel Afet Bilinci } \\
\text { Eğitimi Alma }\end{array}$} \\
\hline \multicolumn{8}{|c|}{ Durumu } \\
\hline Evet & 21 & 43,8 & 17 & 35,4 & 38 & 39,6 & $x^{2}=0,697$ \\
\hline Hayır & 27 & 56,3 & 31 & 64,6 & 58 & 60,4 & $S d=1$ \\
\hline Toplam & 48 & 100 & 48 & 100 & 96 & 100 & $p=0,404$ \\
\hline \multicolumn{8}{|c|}{$\begin{array}{l}\text { Temel Afet Bilinci } \\
\text { Eğitimi Aldığı Yer }\end{array}$} \\
\hline Okul & 9 & 18,8 & 10 & 20,8 & 19 & 50 & $x^{2}=1,115$ \\
\hline AFAD & 11 & 22,9 & 6 & 12,5 & 17 & 44,7 & $\mathrm{Sd}=2$ \\
\hline Diğer & 1 & 2,1 & 1 & 2,1 & 2 & 5,3 & $p=0,573$ \\
\hline Toplam & 21 & 43,8 & 17 & 35,4 & 38 & 100 & \\
\hline
\end{tabular}




\subsection{Grupların eğitim öncesi ve sonrası afete hazırlık durumları}

Bu bölümde grupların afet ve depremlere karşı hazırlık düzeylerinin analizi için eğitim öncesi anket uygulamasındaki bulgular ile eğitimden 2 ay sonra kontrol anketi uygulamasındaki bulgular kullanılmıştır. Aile afet planı hazırlık durumu, afet ve acil durum çantası hazırlık durumu ve aile buluşma noktası belirleme durumuna ilişkin bulgular aşağıda verilmiştir.

\subsubsection{Aile afet planı hazırlama durumuna ilişkin bulgular}

Tablo 2'de görüldüğü gibi eğitim öncesi "Evde Aile Afet Planı yaptınız mı?" sorusuna deney grubu öğrencilerinin \%16,7'si evet, kontrol grubu öğrencilerinin ise \%20,8'i evet olarak yanıtlamışlardır. İki grup arasında aile afet planı hazırlık durumları bakımından istatistiksel olarak anlamlı bir fark bulunamamıştır $(P=0,601)$. Dolayısıyla gruplar aile afet planı yapma durumuna göre birbirine benzerdir.

Eğitim sonrası "Evde Aile Afet Planı yaptınız mı?" sorusuna deney grubu öğrencilerinin \%64,6'sı evet olarak; kontrol grubu öğrencileri ise \%22,9'u evet, yanıtını vermişlerdir. Eğitim sonrasında deney grubunun hazırlık düzeyleri, kontrol grubunun hazırlık düzeylerine göre daha fazla bir artış söz konusudur $(P<0.01)$.

Tablo 2. Grupların Eğitim Öncesi ve Sonrası Aile Afet Planı Hazırlık Durumlarının Değerlendirilmesi

\begin{tabular}{|c|c|c|c|c|c|c|}
\hline & & $\begin{array}{l}\text { Deney } \\
\text { Grubu }\end{array}$ & $\begin{array}{c}\text { Kontrol } \\
\text { Grubu }\end{array}$ & Toplam & $x^{2}$ & $\mathbf{P}$ \\
\hline & & $\mathrm{n}(\%)$ & $\mathrm{n}(\%)$ & $\mathrm{n}(\%)$ & & \\
\hline Eğitim Öncesi & Evet & $8(16,7)$ & $10(20,8)$ & $18(18,8)$ & & \\
\hline Evde Aile Afet & Hayır & $40(83,3)$ & $38(79,2)$ & $78(81,2)$ & 0,274 & 0,601 \\
\hline Planı Hazırlık & Toplam & $48(100)$ & $48(100)$ & $96(100)$ & & \\
\hline Eğitim Sonrası & Evet & $31(64,6)$ & $11(22,9)$ & $42(43,8)$ & & \\
\hline Evde Aile Afet & Hayır & $17(35,4)$ & $37(77,1)$ & $54(56,3)$ & 16,931 & $<0.01$ \\
\hline Planı Hazırlık & Toplam & $48(100)$ & $48(100)$ & $96(100)$ & & \\
\hline
\end{tabular}

\subsubsection{Afet ve acil durum çantası hazırlama durumuna ilişkin bulgular}

Tablo 3'te görüldüğü gibi eğitim öncesinde "Afet ve Acil Durum Çantası Hazırladınız mı?" sorusuna deney grubu öğrencilerinin \%27,1'i evet; kontrol grubu öğrencilerinin ise \%14,6'sı evet, yanıtını vermiştir. Deney ile kontrol grubu afet ve acil durum çantası hazırlık durumları bakımından benzer özelliktedir $(P=0,132)$.

Eğitim sonrasında, "Afet ve Acil Durum Çantası Hazırladınız mı?" sorusuna deney grubunun $\% 45,8$ 'i evet, kontrol grubu ise \%20,8'i evet, yanıtını vermişlerdir. Deney grubu ile kontrol grubu arasında afet ve acil durum çantası hazırlık durumları konusunda istatistiksel olarak aralarında anlamlı bir fark söz konusudur $(P=0,009)$. Eğitim sonrasında deney grubu öğrencilerinin, kontrol grubu öğrencilerine göre afet ve acil durum çantası hazırlık düzeyleri artmıştır.

Tablo 3. Grupların Eğitim Öncesi Afet ve Acil Durum Çantası Hazırlama Durumlarının Değerlendirilmesi

\begin{tabular}{|c|c|c|c|c|c|c|}
\hline & & $\begin{array}{l}\text { Deney } \\
\text { Grubu }\end{array}$ & $\begin{array}{c}\text { Kontrol } \\
\text { Grubu }\end{array}$ & Toplam & $x^{2}$ & $p$ \\
\hline \multirow{4}{*}{$\begin{array}{l}\text { Eğitim Öncesi } \\
\text { Deprem Çantası } \\
\text { Hazırlık Durumu }\end{array}$} & & $\mathrm{n}(\%)$ & $\mathrm{n}(\%)$ & $\mathrm{n}(\%)$ & \multirow{4}{*}{2,274} & \multirow{4}{*}{0,132} \\
\hline & Evet & $13(27,1)$ & $7(14,6)$ & $20(20,8)$ & & \\
\hline & Hayır & $35(72,9)$ & $41(85,4)$ & $76(79,2)$ & & \\
\hline & Toplam & $48(100)$ & $48(100)$ & $96(100)$ & & \\
\hline \multirow{3}{*}{$\begin{array}{l}\text { Eğitim Sonrası } \\
\text { Deprem Çantası } \\
\text { Hazırlık Durumu }\end{array}$} & Evet & $22(45,8)$ & $10(20,8)$ & $32(33,3)$ & \multirow{3}{*}{6,75} & \multirow{3}{*}{0,008} \\
\hline & Hayır & $26(54,2)$ & $38(79,2)$ & $64(66,7)$ & & \\
\hline & Toplam & $48(100)$ & $48(100)$ & $96(100)$ & & \\
\hline
\end{tabular}




\subsubsection{Aile afet buluşma noktası belirleme durumuna ilişkin bulgular}

Tablo 4'te görüldüğü gibi eğitim öncesinde, "Aile afet ve acil durum buluşma noktası belirlediniz mi?" sorusuna deney grubunun \%29,2'si evet, kontrol grubunun ise \%18,8'i evet yanıtını vermişlerdir. Grupların eğitim öncesinde aile afet ve acil durum buluşma noktası belirleme hazırlık oranları birbirlerine benzerdir $(P=0,222)$

Eğitim sonrasında, "Aile afet ve acil durum buluşma noktası belirlediniz mi?" sorusuna deney grubu öğrencilerinin \%64,6'sı evet, kontrol grubu öğrencileri ise \%18,8'i evet, yanıtını vermişlerdir. Deney grubu ile kontrol grubu arasında aile afet ve acil durum buluşma noktası belirleme durumları konusunda istatistiksel olarak aralarında anlamlı bir fark bulunmuştur $(P<0,01)$. Eğitim sonrasında deney grubu öğrencilerinin, kontrol grubu öğrencilerine göre hazırlık düzeyleri daha çok artmıştır.

Tablo 4. Grupların Eğitim Öncesi Aile Afet Buluşma Noktası Belirleme Değerlendirilmesi

\begin{tabular}{ccccccc}
\hline & & $\begin{array}{c}\text { Deney Grubu } \\
\mathbf{n}(\%)\end{array}$ & $\begin{array}{c}\text { Kontrol Grubu } \\
\mathbf{n}(\%)\end{array}$ & $\begin{array}{c}\text { Toplam } \\
\mathbf{n}(\%)\end{array}$ & $\mathbf{x}^{2}$ & $\mathbf{P}$ \\
\hline $\begin{array}{c}\text { Eğitim Öncesi Aile } \\
\text { Afet Buluşma }\end{array}$ & Evet & $14(29,2)$ & $9(18,8)$ & $23(24)$ & & \\
$\begin{array}{c}\text { Noktası Belirleme } \\
\text { Durumu }\end{array}$ & Toplam & $48(70,8)$ & $39(81,2)$ & $73(76)$ & 1,429 & 0,232 \\
\hline $\begin{array}{c}\text { Eğitim Sonrası } \\
\text { Aile Afet Buluşma }\end{array}$ & Evet & $31(64,6)$ & $48(100)$ & $96(100)$ & & \\
$\begin{array}{c}\text { Noktası Belirleme } \\
\text { Durumu }\end{array}$ & Toplam & $47(35,4)$ & $9(18,8)$ & $23(41,7)$ & & \\
\hline
\end{tabular}

Gruplar eğitim öncesinde hazırlık durumları açısından yapılan karşılaştırmada birbirine benzer olduğu görülmüştür. Bu sonuç öğretim tekniklerinin etkisini belirleyebilmek açısından istenen bir sonuçtur. Çalışma grupları eğitim öncesi ve eğitim sonrası olmak üzere afete hazırlık durumları bakımından Mc Nemar testi ile ayrı ayrı değerlendirildiğinde; deney grubunda eğitim öncesine göre, eğitim sonrasında afet hazırlık düzeylerinde artış olduğu saptanmıştır (evde aile afet planı hazırlık durumu $p=0,01$; afet ve acil durum çantası hazırlık durumu $p=0,041$; aile buluşma noktası belirleme durumu $p=0,01$ ), fakat kontrol grubunda eğitim öncesi ve sonrası hazırlık düzeyleri açısından farklılık gözlenmemiştir (aile afet planı hazırlık durumu $p=1$; afet ve acil durum çantası hazırlık durumu $p=0,453$; aile buluşma noktası belirleme durumu $p=1$ ).

\section{Tartışma}

Çalışma, Bursa ilinde sadece Fevzi Çakmak Ortaokulu 7. sınıf öğrencilerini kapsamaktadır. Ayrıca deney grubuna BAEM'de verilen temel afet bilinci eğitimi sadece depremle ilgili simülasyonlar kullanılarak verilmiştir. Diğer simülasyonlarda eğitim verilmemiştir. Araştırmanın bu bakımdan sınırıılıkları bulunmaktadır.

Afetler öncesinde alınan önlemler ve yapılan hazırlıklar olası bir afetten bireylerin maddi ve manevi daha az etkilenmesini sağlamaktadır (Ergünay, 1996). Çalışmada, uygulama öncesinde yapılan değerlendirmede araştırmaya katılan öğrencilerin hazırlık durumlarının çok düşük olduğu görülmektedir.

Grupların uygulama öncesinde demografik özellikleri (yaş, cinsiyet, anne ve baba eğitim durumu) ve afetlere karşı hazırbulunuşluk düzeyleri (aile afet planı hazırlık durumları, aile afet buluşma noktaları belirleme durumları, afet ve acil durum çantası hazırlama durumları) açısından birbirine benzer olması, çalışmanın esasını oluşturan parametreleri anlamlı kılması bakımından önem taşımaktadır. 
Çalışmada eğitim öncesindeki temel afet bilinci eğitimi alma oranı \%39,6'dır. Eğitim alan öğrencilerin \%50'si okuldan, \%44,7'si AFAD tarafından ve \%5,3'ünü diğer kurum ve kuruluşlardan aldığını belirtmişlerdir (Tablo 1). Özgüven (2006) 6. sınıflar üzerinde yaptığı çalışmasında eğitim öncesinde temel afet bilinci eğitimi alanların oranını \%27,6 olarak bulmuştur. Eğitim alanların \%75.8'i televizyon aracılığıyla temel afet bilinci eğitimini aldıklarını belirtmiştir. Pınar (2017)'ın Konya'da ortaokul öğrencileri ile yaptığı çalışmasında öğrencilerin temel afet bilinci eğitimini aldıkları yerin oranlarına bakıldığında ilk sırada okullar, sonra medya ve aile yer almaktadır. İnal (2012) üniversite öğrencilerinin temel afet bilinci ve hazırlık düzeylerine ilişkin yaptığı çalışmasında temel afet bilinci eğitimi aldığını belirtenlerin oranı \%26 olarak saptamıştır. Temel afet bilinci eğitimini alan öğrencilerin \%31'i bu eğitimi okuldan aldığını belirtmiştir. Diğer çalışmalarda temel afet bilinci eğitimi alma yeri olarak AFAD'ın yer almamasının nedeni bulunduğu yerin şartlarıyla ilgili olduğu düşünülmektedir.

Çalışmamızda temel afet bilinci eğitimi alma oranı ve bu eğitimin okullardan alma oranı daha fazla çıkmıştır. Ülkemizde bu alana verilen önemin yıllar geçtikçe arttığı düşünülmektedir. Bu konuda okullarda verilen temel afet bilinci eğitimleri değerlendirildiğinde, MEB'in müfredatına göre hayat bilgisi dersinde doğa olayları ve doğal afetler, sosyal bilgiler dersinde doğal afetler, fen bilimleri dersinde yıkıcı doğa olayları konuları kapsamında anlatılmaktadır (URL4; URL-5 ve URL-6). Müfredata baktığımızda çalışmaya katılan öğrencilerin tümünün bu eğitimleri almış olması gerekmektedir. Bu eğitimler okullarda geleneksel (düz anlatım, gösterip yaptırma) yöntemle anlatıldığı ve dolayısıyla öğrencilerin ilgisini çekmediği için hatırlamadıklarından dolayı almadıklarını söyledikleri düşünülmektedir. Aynı zamanda Öcal (2003) "İlköğretim Sosyal Bilgiler Dersinde Deprem Eğitiminin Değerlendirilmesi” isimli çalışmasında öğretmenlerin deprem eğitimi konusunda yetersiz olduklarını saptamış ve bunun nedenini; lisans düzeyinde afet eğitimi almamış olmaları, teknolojiye ayak uyduramamaları ve deprem eğitimi verilirken animasyon ve simülasyon gibi öğretim yöntemlerinin kullanımının düşük olması olarak açıklamıştır.

Öğretmen adaylarının bilgi düzeyleri, afetlere karşı hazırlık durumları ve afetler konusunda yanlış inanışlara sahip olup olmaması büyük önem arz etmektedir. Groves ve Pugh (1999) ve Lawrenz (1986) öğretmenlerin bazı yanılgılara sahip olması demek öğrencilerinde bu benzer yanılgıların görülme intimalini artırdığını bildirmiştir. Cin, (2010) sınıf öğretmenliği adaylarının temel afet bilinci ile ilgili birçok yanılgıya sahip olduğu ve bu konuda yeterli bilgiye de sahip olmadıkları sonucuna ulaşmıştır. Benzer şekilde Öcal ve diğerleri (2016) sosyal bilgiler öğretmenliği adaylarının afetlerle ilgili birçok yanlış inanışlara ve yetersiz bilgiye sahip olduklarını bildirmiştir. Sözcü ve Aydınözü (2019) sınıf, fen bilimleri ve sosyal bilgiler öğretmen adaylarının doğal afet okuryazarlık düzeylerini belirlemek amacıyla yapmış olduğu çalışmasında öğretmen adaylarının doğal afet bilgileri ve davranışlarının orta düzeyde olduğunu saptamıştır.

Yurt dışında yapılan çalışmalarda farklı farklı sonuçlar bildirilmektedir. Wang ve diğerleri (2012) göre ortaöğretim öğretmenlerinin düşük seviyede bir afet hazırlıklarının olduğunu, Priyowidodo ve Luik (2013) afet hazırlığı kapsamında halkın tsunami konusunda yeterli olmadığını, Chung ve Yen (2016) okul yöneticileri ve öğretmenlerin yüksek düzeyde afet önleme becerilerine sahip olduğunu ortaya koymuştur. Ülkelerin afet politikalarına göre toplumun bilgi ve farkındalık seviyeleri değişmektedir.

Ülkemizde temel afet bilinci ve depremden korunma konularında eğitimler AFAD, ilkokul ve ortaokulda çeşitli dersler bünyesinde, STK'lar, itfaiyeler, üniversiteler vb. kurum ve kuruluşlar tarafından verilmektedir. Doğal afet konuları İlkokul ve ortaokulda çeşitli dersler kapsamında işlenmektedir. Ancak yapılan çalışmalara bakıldığında öğretmen adaylarının afetler konusunda bilgi düzeylerinin istenen seviyede olmadığı görülmektedir. 
2013 Ağustos ayında açılan BAEM, 2013 yılından beri simülasyon eğitimleri ile okullara ve çeşitli resmi kurum ve kuruluşlara hizmet vermektedir. Ancak bu tür simülatörler yardımıyla yapılan eğitimlerin ülkemizde sınırlı sayıda düzenlendiği görülmektedir (URL-7). Çalışmamızın ön testinde "Afet Eğitim Merkezinde daha önceden eğitim aldınız mı?" sorusuna araştırmaya katılan öğrencilerin \%22,9'u Afet Eğitim Merkezi'nde eğitime katıldıklarını söylemişlerdir (Tablo 1). BAEM'de 2016 yılı Ağustos ayı itibariyle 371 okul, resmi özel kurum ve kuruluştan toplam 19217 kişiye eğitim verilmiştir (URL-8). Bursa ilinde Afet Eğitim Merkezi bulunmasına rağmen öğrencilerin bu kurumdan faydalanma oranlarının yeterli olmadığı görülmektedir. Bu konuda okulların daha duyarlı olması beklenmektedir.

Çalışmamız ön test aşamasında "Evde aile afet planı yaptınız mı?" sorusuna, araştırmaya katılan toplam öğrencilerin sadece \%20,8'inin afete karşı yapılmış bir planlarının olduğu, $\% 79,2$ 'sinin ise herhangi bir planlarının olmadığı saptanmıştır (Tablo 2). Deney grubu öğrencilerinin eğitim öncesindeki, aile afet planı hazırlama oranı $\% 16,7$ iken, simülasyon yöntemiyle uygulanan eğitim sonrasında bu oran \%64,6'ya çıkmıştır. Kontrol grubunda ise aile afet planı hazırlama oranı eğitim öncesinde \%20,8 iken, geleneksel yöntemle uygulanan eğitim sonrasında ise bu oran \%22,9 olarak saptanmıştır. Dolayısıyla simülasyon yönteminin daha etkili olduğu görülmektedir. Özgüven (2006) ilköğretim öğrencilerine verilen temel afet bilinci eğitiminin bilgi düzeyine etkisini belirlemek amacıyla 6. sınıf öğrencilerine yaptığı çalışmasında tek bir gruba gösteri, soru cevap, düz anlatım ve gösterip yaptırma yöntemlerini kullanarak deneysel bir çalışma yapmıştır. Eğitim öncesinde aile afet planı hazırlama oranı $\% 37,1$ iken, eğitim sonrasında ise bu oran \%70,4'e çıkmıştır.

Herhangi bir acil durum veya afet anında yardım ekiplerinin olay yerine anında ulaşması pek mümkün değildir. Yardımların olay yerine gelmesi saatler veya günler sürebilir. Bu süre zarfında kendi kendimize hayatta kalmamız gerekmektedir. Bunu sağlamanın yollarından bir tanesi afet ve acil durum çantasıdır. Daha önceden, afet ve acil durum anında acil ihtiyacımız olacak malzemeleri hazırlayıp içine koyduğumuz afet ve acil durum çantası, yardımlar gelinceye kadar kullanmamız açısından büyük önem taşımaktadır (URL-1). Çalışmamızda ön testteki "Afet ve acil durum çantası hazırladınız mı?" sorusuna araştırmaya katılan toplam öğrencilerin \%20,8'i afet ve acil durum çantası hazırlığının olduğunu, \%79,2'sinin ise böyle bir hazırlığının olmadığı saptanmıştır. İnal (2012) üniversite öğrencilerine yapmış olduğu çalışmasında afet ve acil durum çantası hazırlığının olduğunu söyleyenlerin oranını \%30 olarak saptamıştır. Şahin ve diğerlerinin (2018) yapmış olduğu çalışmasında ise üniversite öğrencilerinin afet ve acil durum çantası hazırlığının oranını \%13,7 olarak tespit etmişlerdir.

Afet sonrası buluşma noktaları afet sonrası kriz yönetimi ve güvenlik açısından oldukça önemlidir. Ünal ve diğerleri (2017) Ulusal Medikal Kurtarma Ekibi personeli üzerinde yapmış olduğu çalışmalarında afet ve acil durum buluşma noktası belirleyenlerin oranını \%43,8 olarak saptamışlardır. Bizim çalışmamızda ise yapılan ön testte bulunan "Aile afet ve acil durum buluşma noktası belirlediniz mi?" sorusuna araştırmaya katılan toplam öğrencilerin \%24'ü aile afet ve acil durum buluşma noktası belirlediğini söylemiştir. Diğer çalışmalara göre örneklemin yaş durumuna bakıldığında bu oranın yeterli olduğu söylenebilir. Ancak eğitim sonrasında deney grubunun afet ve acil durum buluşma noktası belirleme durumunun iki katı şeklinde artış olduğu görülmektedir (\%64). Ancak kontrol grubunda herhangi bir değişiklik meydana gelmemiştir.

\section{Sonuç ve Öneriler}

Bu çalışma, Afet Eğitim Merkezi'nde simülasyon öğretim yöntemi aracılığıyla verilen afet eğitimlerinin, okullarda geleneksel yöntemle verilen afet eğitimlerinden daha etkili olduğunu göstermektedir. Dolayısıyla simülasyon yöntemi ile eğitim alan öğrencilerin 2 ay sonraki 
yapılan kontrol testi ile öğrendikleri bilgileri hayata geçirdikleri ve afete hazırlık düzeylerinin arttığı görülmüştür. Bu sonuçlar doğrultusunda önerilerimiz;

- İlkokul ve ortaokul seviyesindeki öğrenciler temel afet bilinci eğitimlerini hayat bilgisi, fen bilimleri ve sosyal bilgiler dersleri kapsamında almaktadırlar. Çalışmamızda eğitim öncesinde yapılan ön testte öğrencilerin hazırlık durumlarının yeterli olmadığı görülmektedir. Bundan dolayı bu konuda öğretmenlere ve okullara büyük görev düşmektedir.

- Öğrencilerin temel afet bilinci kültürünü oluşturmak amacıyla okullar tarafından afet eğitim merkezlerine düzenli aralıklarla ziyaretler düzenlenmelidir.

- Temel afet bilinci eğitimlerinde, bu alanda eğitim almış uzman kişilerden (Örn. Acil Yardım ve Afet Yönetimi mezunları) destek alınabilir.

- Ülkemizde afet eğitim merkezlerinin sayısının artırılması büyük önem arzetmektedir.

\section{KAYNAKLAR}

Akgüngör, Ç. (2013). Sarsıntı başladığında: kitlesel afet eğitimi ve deprem anında birey davranışı örneği. İstanbul Üniversitesi Siyasal Bilgiler Fakültesi Dergisi, (49).29-63.

Arıkan, Z., \& Mergen, S. (2019). Binalardan yangın güvenlik önlemeleri ve maliyet ilişkisi. Zerrin TOPRAK (Ed), Oğuz SANCAKTAR (Ed), Afetler ve güvenlik yönetimi (s. 275-290). Ankara: Palme Yayınevi.

Bee, H., \& Boyd, D. (2009). Çocuk gelişim psikolojisi (Çev. O. Gündüz) Kaknüs Yayınları.

Bilik, M. B. (2017). Sosyo-ekonomik özelliklerine göre bireylerin depreme karşı hazırlık düzeyleri. Zerrin Toprak (Ed), Oğuz Sancaktar (Ed) ve Saadet Illkim Kaya (Ed). Disiplinlerarası afet yönetimi çalışmaları makale kitabı (s.101-106). İzmir: Birleşik Matbaacılık.

Büyüköztürk, Ş., Kılıç Çakmak, E., Akgün, Ö. E., Karadeniz, Ş., \& Demirel, F. (2016). Bilimsel Araştırma Yöntemleri. Ankara: Pegem Yayıncılık.

Cardona, O. D. (2003). The need for rethinking the concepts of vulnerability and risk from a holistic perspective: a necessary review and criticism for effective risk management. $G$. Bankoff, G. Frerks, D. Hilhorst (Eds). Mapping vulnerability: Disasters, development and people, (s. 37-51). London : Earthscan Publishers.

Chung, S. C., \& Yen, C.-J. (2016). Disaster prevention literacy among school administrators and teachers: A study on the plan for disaster prevention and campus network deployment and experiment in Taiwan. Journal of Life Sciences, 10, 203-214

Cin, M. (2010). Sınıf öğretmeni adaylarının doğal afetler ile ilgili yanılgıları. Marmara Coğrafya Dergisi, (22), 70-81.

Dikmenli, Y., \& Yakar, H. (2019). Öğretmen adaylarının afet bilinci algı düzeylerinin incelenmesi. Yüzüncü Yıl Üniversitesi Eğitim Fakültesi Dergisi, 16 (1), 386-416.

Doğan, E., \& Koç, H. (2017). Sosyal bilgiler dersinde deprem konusunun dijital oyunla öğretiminin akademik başarıya etkisi. Uluslararası Türk Eğitim Bilimleri Dergisi, (8), 90-100. 
Erdoğ, S.T. (2010). Illköğretim 4. sınıf sosyal bilgiler dersinde hava olayları, iklim ve deprem ile ilgili konuların öğretiminde aktif öğrenme yöntemlerinin etkisi (Yüksek Lisans Tezi). Gazi Üniversitesi Eğitim Bilimleri Enstitüsü, Ankara.

Ergünay, O. (1996). Afet yönetimi nedir? Nasıl olmalıdır? Erzincan ve Dinar deneyimleri ışığında Türkiye'nin deprem sorunlarına çözüm arayışları. Tübitak Deprem Sempozyumu.

Ergünay, O. (2007). Türkiye"nin afet profili. TMMOB Afet Sempozyumu Bildiriler Kitabı, 5-7.

Groves, F. H., \& Pugh, A. F. (1999). Elementary pre-service teacher perceptions of the greenhouse effect. Journal of Science Education and Technology, 8(1), 75-81.

Kalkınma Bakanlığı (2019), On Birinci Kalkınma Planı (2019 - 2023), Özel İhtisas Komisyonları ve Çalışma Grupları El Kitabı, Ankara: Kalkınma Bakanlığı Yayını.

Karaesmen, E. (2002). Öncesiyle sonrasıyla deprem. Ankara: Atıım Üniversitesi Yayınları.

Karakuş, U. \& Önger, S. (2017). 8. sınıf öğrencilerinin doğal afet ve afet eğitimi kavramını anlama düzeyleri. Journal of History Culture and Art Research, 6(6), 482-491.

Karancı, A. N., Aksit, B., \& Dirik, G. (2005). Impact of a community disaster awareness training program in Turkey: Does it influence hazard-related cognitions and preparedness behaviors. Social Behavior and Personality: An International Journal, 33(3), 243-258.

Karataş, O. (2011). IIlköğretim I. kademe sosyal bilgiler dersi doğal afet eğitiminde drama tekniğinin öğrencilerin başarılarına etkisi: Deneysel çalışma. (Yayınlanmamış Yüksek Lisans Tezi). Kafkas Üniversitesi Sosyal Bilimler Enstitüsü, Kars.

Kaya, E., \& Özcebe, H. (2012). Afetlerin çocuk sağlığı üzerindeki etkileri. TAF Preventive Medicine Bulletin, 12(4), 455-460

Kırıkkaya, E., Ünver, A., \& Çakın, O. (2011). İlköğretim fen ve teknoloji programında yer alan afet eğitimi konularına ilişkin öğretmen görüşleri. Necatibey Eğitim Fakültesi Elektronik Fen ve Matematik Eğitimi Dergisi, 5 (1), 24-42

Lawrenz, F. (1986). Misconceptions of physical science concepts among elementary school teachers. School Science and Mathematics, 86(8), 654-60.

İnal, E., Kocagöz, S., \& Turan, M. (2012). Temel afet bilinç ve hazırlık düzeyinin saptanmasına yönelik bir araştırma. Türkiye Acil Tıp Dergisi, 12, 15-1

Oğuz, A., (2005). Surveying American and Turkish middle school students' existing knowledge of earthquakes by using a systematic network, (Unpublished PhD Theses). Ohio State University, USA.

Öcal, A. (2003). Illköğretim sosyal bilgiler dersinde deprem eğitiminin değerlendirilmesi, (Yayınlanmamış Yüksek Lisans Tezi).Gazi Üniversitesi Eğitim Bilimleri Enstitüsü, Ankara.

Öcal, A., Yıldıım, E., Yakar, H., \& Erdoğan, E. (2016). Sosyal bilgiler öğretmen adaylarının afetlere yönelik inanışlarının incelenmesi. Kırıkkale Üniversitesi Sosyal Bilimler Dergisi, 6(2). 
Özgüven, B. (2006). İlköğretim öğrencilerine verilen temel afet bilinci eğitiminin bilgi düzeyine etkisi, (Yüksek Lisans Tezi). Dokuz Eylül Üniversitesi Sağlık Bilimleri Enstitüsü, İzmir

Özmen, B., \& Özden, A. T. (2013). Türkiyenin afet yöneimine ilişkin eleştirel bir değerlendirme. i.Ü. Sosyal Bilgiler Fakültesi Dergisi, 49, 1-28.

Özmen, B., \& İnce, Z. D. (2017). Okul tabanlı afet eğitimi. Resilience, 1(1), 21-29.

Pınar, A. (2017). What is secondary school students' awareness on disasters? A case study. Review of International Geographical Education Online, 7(3), 315-331.

Priyowidodo, G., \& Luik, J. E. (2013). Communicating Disaster Mitigation Literacy to Coastal Communities in Pacitan Indonesia. American International Journal of Research in Humanities, Arts and Social Sciences, 5(2), 245-248.

Sanduvac, Z., M., \& Petal, M., (2010)."History of School Seismic Safety in Turkey." Seminar Series on Disaster Education in the UK

Sharp, J.G., Mackintosh, M.A.P., \& Seedhouse, P. (1995). Some comments on children's ideas about earth structure, volcanoes, earthquakes and plates. Teaching Earth Sciences, 20(1), 28-30.

Sözcü, U., \& Aydınözü, D. (2019). Öğretmen adaylarının doğal afet okuryazarlık düzeylerinin belirlenmesi. International Journal of Geography and Geography Education, (40), 79-91.

Şahin, Y., Lamba, M., \& Öztop, S. (2018). Üniversite öğrencilerinin afet bilinci ve afete hazırlık düzeylerinin belirlenmesi. Medeniyet Araştırmaları Dergisi, 3(6), 149-159.

Şimşek, C. (2007). Children's ideas about earthquakes. Journal of Environmental \& Science Education, 2 (1),14-19

Turan, İ., \& Kartal, A. (2012). İlköğretim 5. sınıf öğrencilerinin doğal afetler konusu ile ilgili kavram yanılgıları. Ahi Evran Üniversitesi Kırşehir Eğitim Fakültesi Dergisi, 13(3), 67-81.

UNISDR (United Nations International Strategy for Disaster Reduction). (2005, March). Hyogo framework for action 2005-2015: building the resilience of nations and communities to disasters. In Extract from the final report of the World Conference on Disaster Reduction (A/CONF. 206/6) (Vol. 380).

UNISDR (United Nations International Strategy for Disaster Reduction). (2009). Terminology. Geneva: UNISDR.

Ünal, Y., Işık, E., Şahin, S., \& Yeşil, S. T. (2017). Sağlık Afet çalışanlarının depremlere ilişkin bireysel hazırlık düzeylerinin değerlendirilmesi: Ulusal Medikal Kurtarma Ekipleri (UMKE) Derneği örneği. Dokuz Eylül Üniversitesi Tıp Fakültesi Dergisi, 31(2), 71-80.

Varol, N., \& Kırıkkaya, E. B. (2017). Afetler Karşısında Toplum Dirençliliği. Resilience, 1(1), 1-9.

Wang, M., Wel, D. Y., Zhu, X. L., \& YI, N. (2012). An investigation on disaster prevention literacy of secondary school teachers in China. Journal of Educational Studies, 5, 12. 
URL-1: Afet ve Acil Durum Yönetim Başkanlığı (AFAD). Afete Hazır Türkiye Projesi. Erişim: https://www.afad.gov.tr/afete-hazir-turkiye-projesi'den 20.09.2020'de alınmıştır.

URL-2: Türk İşbirliği Koordinasyon Ajansı Başkanlığı (TİKA). Afet Risklerinin Yönetimi ve Afetlere Karşı Dirençli Toplumların Oluşturulması Eğtimi. Erişim: http://www.tika.gov.tr/tr/haber/afet_risklerinin_yonetimi_ve_afete_karsi_direncli_toplumlarin_ olusturulmasi_egitimi-36405'den 21.09.2020'de alınmıştır.

URL-3: Vicovic, D. Why the First 72 Hours After a Disaster Are Critical. Erişim: https://www.primalsurvivor.net/why-the-first-72-hours-after-a-disaster-are-critical/'den 21.09.2020'de alınmıştır.

URL-4: Milli Eğitim Bakanlığı (MEB). 2018 Yılı Sosyal Bilgiler Dersi Öğretim Programı. Erişim: http://mufredat.meb.gov.tr/ProgramDetay.aspx?PID=354'den 20.09.2018'de alınmıştır.

URL-5: Milli Eğitim Bakanlığı (MEB). 2018 Yılı Fen Bilimleri Dersi Öğretim Programı. Erişim: http://mufredat.meb.gov.tr/Dosyalar/201812312311937-

FEN\%20B\%C4\%BOL\%C4\%BOMLER\%C4\%B0\%20\%C3\%96\%C4\%9ERET\%C4\%B0M\%20P ROGRAMI2018.pdf'den 20.09.2018'de alınmıştır.

URL6: Milli Eğitim Bakanlığı (MEB). 2018 Yılı Hayat Bilgisi Dersi Öğretim Programı. Erişim: http://mufredat.meb.gov.tr/Dosyalar/2018122171428547-

HAYAT\%20B\%C4\%B0LG\%C4\%B0S\%C4\%B0\%C3\%96\%C4\%9ERET\%C4\%B0M\%20PRO GRAMI.pdf'den 20.09.2018'de alınmıştır.

URL-7: Afet ve Acil Durum Yönetim Başkanlığı (AFAD). Bursa Afet Eğitim Merkezi. Erişim: https://bursa.afad.gov.tr/afet-egitim-merkezi' den 20.09.2020'de alınmıştır.

URL-8: Afet ve Acil Durum Yönetim Başkanlığı (AFAD). Afet ve Acil Durum Çantası. Erişim: https://www.afad.gov.tr/kbrn/afet-ve-acil-durum-cantasi'den 20.09.2020'de alınmıştır. 